International Journal Of Occupational Health and Public Health Nursing,

Vol. 7, No. 2, 2021, 1-12

ISSN: 2053-2369 (print version), 2053-2377 (online)

https://doi.org/10.47260/johphn/721

Scientific Press International Limited

\title{
Employers' Perceptions of Work Ability Knowledge Management in Collaboration with Occupational Health Services
}

\author{
Nissinen Sari', Soini Satu ${ }^{2}$ and Helena Palmgren ${ }^{3}(\dagger)$
}

\begin{abstract}
Good collaboration between employers and occupational health services (OHS) requires smoothly flowing information exchange, which can be used to improve work ability (WA) management. Our aim was to examine WA knowledge management in the collaboration between workplaces and OHS. The data were collected via telephone interviews in which 154 employers participated. The results showed that the relevant WA data were available when needed and, in the form needed. The most relevant data were assessments of work capacity, suspected occupational diseases, health and work hazards, and workload factors. WA data enables the identification of people whose WA is at risk and the coordination of measures to support their coping at work or return to work after sick leave. We also identified the main needs for knowledge and current practices of WA knowledge management. Further research is needed, especially on the bottlenecks in knowledge flows.
\end{abstract}

Keywords: Health information exchange, Knowledge Management, Medical records, Occupational health services, Workplace.

${ }^{1}$ Senior Specialist, PhD, Finnish Institute of Occupational Health.

2 Chief Physician, M.D., Finnish Institute of Occupational Health.

$3(\dagger)$ deceased. Head of Development, PhD, Finnish Institute of Occupational Health

Article Info: Received: August 25, 2021. Revised: September 10, 2021.

Published online: September 27, 2021. 


\section{Introduction}

It is the employers' responsibility to ensure that work is healthy and safe, and to prevent accidents and work-related illnesses. In Finland, work ability support is part of the statutory obligations of employers and occupational health services (OHS). [1] It requires collaboration and practices agreed on by the employer and OHS. [2] The effectiveness of work ability management is enhanced by long-term collaboration between employers and OHS, frequent contact and the exchange of information regarding employees' health and work ability. However, in challenging and sensitive work ability issues, the confidentiality of patient care must be ensured. [3-5]

The collaboration between a workplace and its OHS is guided by three principles. First is the principle of awareness, which applies to information on employees' work ability and their state of health, the risks related to work, and psychological and physical workload. Another guiding principle for collaboration is preparation, which includes preventive measures and early interventions to support work ability. The third principle is participation, which involves clarifying whether an employee is able to return to work after prolonged incapacity to work. It is essential that both parties act in accordance with these principles. [6] However, collaboration between employers and OHS is not always carried out as planned. [7]

Employees' work ability can change during different phases of the working career, even during early working years. Work capacity and health problems are significant predictors of sick leaves and eventually permanent disability. Furthermore, employees' perceived work ability may predict disability retirement or unemployment. [8-11] OHS produces information regarding situations that threaten the health and work ability of employees. This information is accumulated in health check-ups and medical visits. $[12,13]$

Good collaboration between employers and OHS includes smoothly flowing information exchange. [3] An essential factor in this collaboration is that employers gain relevant information on employees' work ability [14], which can be used to improve work ability management in workplaces. [15] Employees with work ability problems can be supported through good collaboration between their employer and OHS, also during an employees' disability period and when returning to work. [8] Employers expect good reporting from OHS. [16] Reports should include workplace-specific information and observations of employees' health and wellbeing. Employers also want information regarding employees' work restrictions, prognostic assessments of whether these work restrictions are temporary or permanent [17], and information on whether workplace accommodations are needed. [18] Employers want this information exchange to be active, up to date and comprehensible. Thus, the information obtained can be used to improve work and working conditions and to support employees' work ability. [19, 20]

Knowledge management can be defined as a process of creating, sharing, using, and managing the knowledge and information in an organization. Knowledge management is related to the effective dissemination of information and its 
utilization in organizational problem-solving and decision-making. [21] Knowledge management processes should begin by focusing on the organizations' information needs and end with the use of the knowledge. [22]

Collaboration between the employer and OHS is a prerequisite for effective work ability management. The knowledge processes of the collaboration should always be tightly connected to the provision of occupational health services to employers. [23] Occupational health professionals are used to providing employees with information about work ability and health, but the provision of information to employers needs to be improved. [24]

This study is based on Choo's information management process model. Choo explored how organizations use information for decision making. The process model describes information management as a continuous cycle of six interrelated functions: 1) information needs, 2) information acquisition, 3) information organization and storage, 4) information products and services, 5) information distribution, and 6) information use. In our study, the focus was on three phases of the information management process model: identifying information needs (important work ability data), information distribution (having work ability data), and information use (work ability data available when needed). [22]

The aim of this study was to examine knowledge management collaboration between workplaces and OHS for supporting employees' work ability. The research question was: What does work ability knowledge management consist of (information needs, distribution and use of work ability data) in collaboration between workplaces and OHS?

\section{Materials and methods}

The study used structured telephone interviews, conducted in November and December 2020. Ethical approval for the study was provided by the Ethics Committee of the Finnish Institute of Occupational Health on September 3, 2020. A random sample of 1000 employers was chosen from The Social Insurance Institution of Finland's database of employers who had applied for compensation for OHS costs in 2014-2016. The sample consisted of 200 employers with 1-19 employees, and 800 employers with 20 or more employees. The employers' contact information was checked and a request to participate in the telephone interview was sent via SMS. Of these employers, 383 did not respond to the request or could not be reached because of invalid contact information. The final sample size was 617 employers. Of these, 462 declined to participate, and one interview was interrupted by the participant. Thus, the total number of study participants was 154 and the response rate was 25 .

The content of the interview was based on earlier studies. [25, 26] Respondents were asked to rate the importance of different information for supporting employees' work ability using a four-point Likert scale, in which 1 indicated 'Not important at all' and 4 indicated 'Very important'. They could also answer an open 
question about what they regarded as important work ability data. The interview form included multiple-choice questions about the distribution and use of work ability data with a four-point Likert scale, in which 1 indicated 'strongly agree', and 4 indicated 'strongly disagree'. The scale of one variable was inverted parallel to the other variables.

The interview form was tested by four work ability management and human resource professionals and finalized after their comments. The results were reported as quantities and percentages. Differences in participants' responses were analysed using the chi-square test. Statistical significance was defined as $p<0.05$. The statistical analyses were performed using the SPSS Statistics 25 package. The answers to the open questions were narrative text, which was examined by inductive content analysis using Excel software. In addition, we calculated how many times respondents gave similar statements on the subject matter.

\section{Main Results}

This study's participants were 154 employers from eleven industry sectors, the most common being manufacturing $(22 \%)$ and human health and social work activities $(14 \%)$. The most common occupations of the respondents were managing director or chief executive officer (38\%), human resources officer $(26 \%)$ or administrative officer (14\%). Most often, the respondents were employers with 50 to 249 employees $(35 \%)$ who had cooperated with their current OHS provider for at least five years $(61 \%)$ and were satisfied with their OHS (82\%). Two out of five employers communicated with their OHS a few times a year $(41 \%)$ and two out of three were satisfied with their own organization's work ability management measures $(68 \%)$. Table 1 summarizes the participants' characteristics.

Table 1: Characteristics of participants $(n=154)$

\begin{tabular}{|c|c|c|}
\hline Characteristic & Frequency (n) & Percentage (\%) \\
\hline \multicolumn{3}{|l|}{ Industry } \\
\hline Manufacturing & 32 & 22 \\
\hline Human health and social work activities & 22 & 14 \\
\hline Public administration and defence & 15 & 10 \\
\hline Professional, scientific and technical activities & 14 & 9 \\
\hline Education & 11 & 7 \\
\hline Other service activities & 11 & 7 \\
\hline Agriculture, forestry and fishing & 8 & 5 \\
\hline Wholesale and retail trade & 8 & 5 \\
\hline Construction & 6 & 4 \\
\hline Administrative and support service activities & 6 & 4 \\
\hline Other industry & 20 & 13 \\
\hline
\end{tabular}




\begin{tabular}{|c|c|c|}
\hline \multicolumn{3}{|c|}{ Occupation } \\
\hline Managing director/ chief executive officer & 59 & 38 \\
\hline Other expert & 6 & 4 \\
\hline Human recourse officer & 40 & 26 \\
\hline Administrative officer & 22 & 14 \\
\hline Finance officer & 15 & 10 \\
\hline Other director & 7 & 5 \\
\hline Occupational safety and health expert & 5 & 3 \\
\hline \multicolumn{3}{|c|}{ Number of employees } \\
\hline $1-9$ & 12 & 8 \\
\hline $10-19$ & 19 & 12 \\
\hline $20-49$ & 44 & 29 \\
\hline $50-249$ & 54 & 35 \\
\hline 250 or more & 25 & 16 \\
\hline \multicolumn{3}{|c|}{ Duration of contract with OHS } \\
\hline Under 1 year & 11 & 7 \\
\hline $1-4$ years & 49 & 32 \\
\hline 5 or more years & 94 & 61 \\
\hline \multicolumn{3}{|c|}{ Communication with OHS } \\
\hline Less frequently than once a year & 7 & 5 \\
\hline Once a year & 51 & 33 \\
\hline A few times a year & 64 & 41 \\
\hline Monthly & 26 & 17 \\
\hline Weekly & 6 & 4 \\
\hline \multicolumn{3}{|c|}{ Satisfaction with OHS activities } \\
\hline Excellent & 53 & 34 \\
\hline Good & 73 & 48 \\
\hline Moderate & 28 & 18 \\
\hline \multicolumn{3}{|c|}{ Satisfaction with organization's own work ability management* measures } \\
\hline Excellent & 26 & 18 \\
\hline Good & 71 & 50 \\
\hline Moderate & 45 & 32 \\
\hline
\end{tabular}

We asked the participants $(n=154)$ how important certain types of work ability data are for supporting employees' work ability. Most of them considered occupational health professionals' assessments of work capacity and ability to cope at work (70\%), and employees' assessments of work capacity and ability to cope at work $(64 \%)$ to be very important data. Suspected occupational diseases $(61 \%)$, health and work hazards $(58 \%)$, workload factors $(56 \%)$, and need for rehabilitation $(50 \%)$ 
were also seen as very important information. The diagnosis or symptoms of a disease $(18 \%)$ and work relatedness of a disease $(15 \%)$ were most often considered not at all important or not very important information for supporting employees' work ability. (Table 2.)

Table 2: Employers' perceived importance of work ability data $(n=154)$

\begin{tabular}{|l|c|c|c|c|c|}
\hline $\begin{array}{c}\text { How important do you } \\
\text { consider the following data } \\
\text { for supporting employees' } \\
\text { work ability? }\end{array}$ & $\begin{array}{c}\mathbf{1} \\
\mathbf{( \% )}\end{array}$ & $\begin{array}{c}\mathbf{2} \\
\mathbf{( \% )}\end{array}$ & $\begin{array}{c}\mathbf{3} \\
\mathbf{( \% )}\end{array}$ & $\begin{array}{c}\mathbf{4} \\
\mathbf{( \% )}\end{array}$ & $\begin{array}{l}\text { Means on scale 1-4 } \\
\text { 1=Not important at all } \\
\text { 2=Not so important } \\
\text { 3=Important } \\
\text { 4=Very important }\end{array}$ \\
\hline Health & 0 & 1 & 41 & 58 & 3.56 \\
\hline $\begin{array}{l}\text { Diagnosis or symptoms of a } \\
\text { disease }\end{array}$ & 2 & 18 & 46 & 34 & 3.13 \\
\hline Work-relatedness of a disease & 4 & 15 & 47 & 34 & 3.11 \\
\hline Need for rehabilitation & 1 & 1 & 48 & 50 & 3.47 \\
\hline $\begin{array}{l}\text { Employee's assessment of work } \\
\text { capacity and ability to cope at } \\
\text { work }\end{array}$ & 1 & 2 & 33 & 64 & 3.61 \\
\hline $\begin{array}{l}\text { Occupational health } \\
\text { professional's assessment of } \\
\text { work capacity and ability to } \\
\text { cope at work }\end{array}$ & 0 & 1 & 29 & 70 & 3.69 \\
\hline $\begin{array}{l}\text { Health check-up's statement on } \\
\text { ability to work }\end{array}$ & 2 & 12 & 42 & 45 & 3.29 \\
\hline $\begin{array}{l}\text { Work hazard and workload } \\
\text { factors }\end{array}$ & 0 & 5 & 39 & 56 & 3.51 \\
\hline Job resources & 1 & 6 & 54 & 39 & 3.31 \\
\hline Need for work modifications & 1 & 9 & 54 & 36 & 3.26 \\
\hline Suspected occupational disease & 2 & 5 & 32 & 61 & 3.52 \\
\hline
\end{tabular}

Without giving them ready-made response options, we asked the participants what other information related to work ability support they considered important. Thirtyfive answered this question. A stressful life situation was mentioned most often (40\%). Work life skills (32\%), and lifestyle (17\%), and medical history (11\%) were also considered important information for work ability support.

Almost all $(90 \%)$ the participants $(n=154)$ agreed that relevant work ability data were available when needed and about three quarters (77\%) agreed that the data were in the form needed. Over half (53\%) agreed that OHS provided work ability data on a regular basis. Clearly more than half $(61 \%)$ of the participants felt that the method of sharing work ability data with OHS should be improved. (Figure 1.) 


\section{Knowledge management of work ability data in workplaces}

\section{$(\mathbf{n}=\mathbf{1 5 4})$}

The relevant work ability data are available when needed.

The relevant work ability data are available in the form which is needed.

The necessary data are easily obtained from the employee.

The necessary data are easily obtained from occupational health services.

Occupational health services provide a great deal of necessary work ability data.

Occupational health services provide work ability data on a regular basis.

The method of sharing the work ability data has been agreed on occupational health...

The method of sharing the work ability data with occupational health services needs to..

The occupational health extranet service can be used to exchange work ability data.
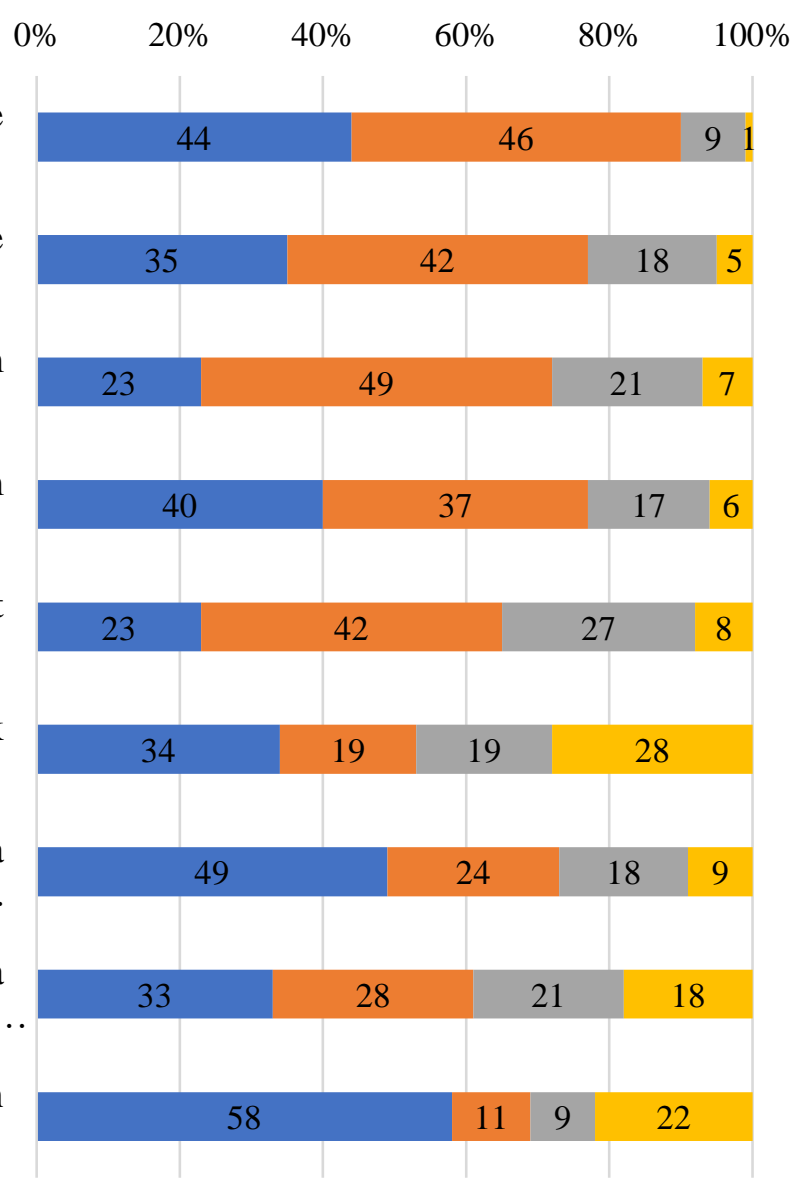

$\square$ Strongly agree $\square$ Agree $\square$ Disagree $\square$ Strongly disagree

Figure 1: Employers' experiences of work ability knowledge management in collaboration with occupational health services $(n=154)$

We compared the responses to the participants' characteristics and found a few statistically significant results. The employers whose satisfaction with $\mathrm{OHS}$ activities was good or excellent more often felt that they received employees' work ability data regularly $(\mathrm{p}=0.003)$. They also felt that the work ability data exchange with OHS was jointly agreed upon $(\mathrm{p}=0.017)$. Employers with less than 50 employees disagreed more often than employers of larger enterprises that they received work ability data regularly $(\mathrm{p}=0.005)$. The results also revealed a need to develop the method of sharing work ability data. This opinion was most often expressed by those whose satisfaction with OHS was at an excellent level $(p=0.005)$. Moreover, the majority of those whose satisfaction with the OHS activities was good or excellent agreed that OHS provided work ability data as needed $(\mathrm{p}=0.024)$. 


\section{Discussion}

Finnish legislation emphasizes addressing threats to work capacity and health as early as possible. The collaboration and clear responsibilities of employers and OHS in this regard stress the importance of managing work ability at the workplace. [15] Work ability management should be based on good knowledge management, in which existing information systems play a key role. The utilization of information is a joint activity of employers and OHS to prevent or solve work ability problems, help make decisions, and support employees' ability to cope at work. Because OHS information systems contain highly important and valuable patient data, it is important that this data can be used for employers' managerial purposes, such as managing their employees' work ability. [23]

The study contributed to our understanding of the collaboration between employers and OHS, especially in the knowledge management of work ability. According to our results, the employers felt that the most important work ability data obtained from OHS were assessments of work capacity, ability to cope at work (work ability), health, suspected occupational diseases, work hazards and workload factors, and the need for rehabilitation.

Although information exchange can support organizational performance, it also poses serious challenges related to the different information systems in the crossfunctional information exchange of confidential patient data. [23, 27] Furthermore, there is an even wider need to develop the collaboration between OHS and their client organizations. [28] Our results showed that well over half of the respondents had agreed on the way of sharing work ability data with OHS but felt that it still needed further development.

According to our results, employers with less than 50 employees did not receive work ability data from OHS regularly. OHS should offer work ability data to all employers on a regular basis, irrespective of company size. Small enterprises should also collaborate with their OHS regularly and be able to utilize the non-confidential data that OHS possess for supporting their employees' work ability. It should be noted that work ability has both human and social significance. Good work ability usually means good functional ability both at work and after work life.

Occupational health professionals record a great deal of patient data related to work ability. This data enables the identification of people whose work ability is at risk and supports their ability to cope at work or helps their return to work after sick leave. This is the information that employers want to use for supporting employees' work ability. However, despite the interest in work ability data, employees' individual privacy and data protection must always be adhered to. 


\section{Limitations}

As this was a small-scale study of the rarely studied phenomenon of work ability knowledge management, generalization of the findings must be done with caution. The first limitation of the study is its sample size and the second is that the data were collected as part of a larger survey, which limited the number of questions related to work ability support and its knowledge management. The third limitation is the lack of previous studies on the topic. Future research could take a wider scope and have larger sample sizes. From the perspective of knowledge management, more research is needed, especially on the bottlenecks in information flows. It would be interesting to study how to move from data collection to smooth data utilization. Interesting issues in the collaboration between employers and OHS are, for example, the timeliness, quality, and relevance of work ability data.

\section{Conclusion}

This study revealed the main knowledge needs of employers, and the current practices of work ability knowledge management. The knowledge management methods in the collaboration with OHS helped employers manage employee work ability. The findings of this study have implications for future practice: for example, improving work ability knowledge management practices, and information systems for reliable and up-to date work ability information exchange. Furthermore, the collaboration between OHS and workplaces should be strengthened to ensure that all workplaces are able to manage their employees' work ability with the help of OHS. This requires informing employers of the importance and benefits of work ability knowledge management and paying more attention to this in the professional training of occupational health personnel. Occupational health professionals' training is also important for developing documentation practices related to the relevant work ability data.

CONFLICTS OF INTEREST. The author(s) declare no potential conflicts of interest with respect to the research, authorship, and/or publication of this article.

AUTHOR CONTRIBUTIONS. All the authors equally contributed to writing this article. All the authors have read the final version and agree with its content.

FUNDING. This study was partially funded by the European Social Fund (The TYKYTUO project of the Finnish Institute of Occupational Health).

ACKNOWLEDGEMENTS. The authors would like to express their deep respect to our colleague, $\mathrm{PhD}$ Helena Palmgren, who suddenly passed away in the middle of the publishing process of this article. We shall greatly miss her wise thoughts and comments and especially her experiences of occupational health and safety and knowledge management in enterprises. 


\section{References}

[1] Occupational Health Care Act 1383/2001. https://www.finlex.fi/en/laki/kaannokset/2001/en20011383.pdf

[2] Taskinen, H. (1997). Good occupational health practice: A guide for planning and follow-up of occupational health services. Helsinki: Ministry of Social Affairs and Health, Finnish Institute of Occupational Health, 1997. https://www.julkari.fi/handle/10024/135113

[3] Halonen, J., Atkins, S., Hakulinen, H., Pesonen, S. and Uitti, J. (2017). Collaboration between employers and occupational health service providers: a systematic review of key characteristics. BMC Public Health, 17(1), (2017), 1-9. doi:10.1186/s12889-016-3924-x

[4] Schmidt, L., Sjöström, J., Antonsson, A.B. (2015). Successful collaboration between occupational health service providers and client companies: Key factors. Work, 51(2), (2015), 229-237. doi:10.3233/WOR-141855

[5] Schmidt, L., Sjöström, J., Antonsson, A.B. (2012). How can occupational health services in Sweden contribute to work ability? Work, 41(1), (2012), 2998-3001. doi:10.3233/WOR-2012-0555-2998

[6] Martimo, K.P., Mäkitalo, J. (2014). The status of occupational health services in Finland and the role of the Finnish Institute of Occupational Health in the development of occupational health services. Report for the international evaluation of the Finnish Institute of Occupational Health (FIOH). 2014. https://www.julkari.fi/handle/10024/135062

[7] Sormunen, E., Ylisassi, H., Mäenpää-Moilanen, E., Remes J., Pekka-Martimo, K. (2020). Co-operation in the prevention of work disability due to musculoskeletal disorders: A cross-sectional study among occupational health professionals in Finland. Work, 67(3), (2020), 697-708. doi:10.3233/WOR203319. PMID: 33185626

[8] Leino-Arjas, P, Seitsamo, J, Nygård, C.H., Prakash, K.C., Neupane, S. (2021). Process of Work Disability: From Determinants of Sickness Absence Trajectories to Disability Retirement in A Long-Term Follow-Up of Municipal Employees. International Journal of Envirnomental Research and Public Health, 18(5), (2021), 2614. doi.org/10.3390/ijerph18052614

[9] Hynninen, Y, Voltti, S, Pohjonen, T., Tuovinen, E., Leskela, R.L. (2020).

Työntekijän koettu työkyky ennustaa sairauspoissaoloja ja työterveyshuollon kustannuksia [Employees' perceived work ability predicts sickness absences and occupational health care costs]. Suomen Lääkärilehti, 75(41), (2020), 2138-2143. (English summary)

https://www.laakarilehti.fi/tieteessa/alkuperaistutkimukset/tyontekijankoettu-tyokyky-ennustaa-sairauspoissaoloja-ja-tyoterveyshuollonkustannuksia/

[10] Kinnunen, U., Nätti, J. (2018). Work ability score and future work ability as predictors of register-based disability pension and long-term sickness absence: 
A three-year follow-up study. Scand J Public Health. 46(3), (2018), 321-330. doi:10.1177/1403494817745190.

[11] Jääskeläinen, A., Kausto, J., Seitsamo, J., Ojajärvi, A., Nygård, C.H., Arjas, E., Leino-Arjas, P. (2016). Work ability index and perceived work ability as predictors of disability pension: a prospective study among Finnish municipal employees. Scand J Work Environ Health, 42(6), (2016), 490-499. doi:10.5271/sjweh.3598.

[12] Ikonen, A., Räsänen, K., Manninen, P., Rautio, M., Husman, P., Ojajärvi, A., Husman, K. (2012). Work-related primary care in occupational health physician's practice. J Occup Rehabil, 22(1), (2012), 88-96. https://doi.org/10.1007/s10926-011-9325-1

[13] Kimanen, A., Rautio, M., Manninen, P., Räsänen, K., Husman, P., Husman, K. (2011). Primary care visits to occupational health physicians and nurses in Finland. Scand J Public Health, 39(5), (2011), 525-32. https://doi.org/10.1177/1403494811399651

[14] Lappalainen, L., Liira, J., Lamminpää, A. (2021). Work disability negotiations between supervisors and occupational health services: factors that support supervisors in work disability management. Int Arch Occup Environ Health, 94(4), (2021), 689-697. doi.org/10.1007/s00420-020-01623-5

[15] Pehkonen, I., Turunen, J., Juvonen-Posti, P. Henriksson, L., Vihtonen, T., Seppänen, J., Liira, J., Uitti, J., Leino, T. (2017).

Yhteistyöllä tulosta työkykyjohtamisessa: Moniaineisto- ja monimenetelmätutkimus. [Achieving the results with the collaboration in work ability management: Multi-material and multi-methodological research]. Tietoa työstä. Työterveyslaitos [Finnish Institute of Occupational Health]. 2017. http://urn.fi/URN:ISBN 978-952-261-727-9 (PDF) (Abstract in English)

[16] Hakulinen, H., Pirttilä, I. (2012).Asiakkuus työterveyshuollon ja asiakasorga nisaation tulkinnoissa [A customer relationship in the interpretations of occupational health services and employer clients]. Työelämän tutkimus, 10(3), (2012), 262-280. [Only in Finnish)

[17] Williams-Whitt, K., Kristman, V., Shaw, W.S., Soklaridis, S., Reguly, P. (2016). A model of supervisor decision-making in the accommodation of workers with low back pain. J Occup Rehabil, 26(3), (2016), 366-381. doi.10.1007/s10926-015-9623-0

[18] Lappalainen, L., Liira, J., Lamminpää, A., Rokkanen, T. (2019). Work disability negotiations: supervisors' view of work disability and collaboration with occupational health services. Disabil Rehabil, 41(17), (2019), 2015-2025. doi:10.1080/09638288.2018.1455112

[19] Heikkinen, A. (2007). Työterveyshuollon asiakasyritykset odottavat kumppanuus-yhteistyöltä merkittävää vaikuttavuutta [Co-operation between occupational health services and client companies]. Suomen Lääkärilehti, 62(46), (2007), 4333-4337. (Only in Finnish) 
[20] Halonen, K. (2013). Always a little behind - relying on chance - A study on people risk management as a strategic management tool carried out by Finnish organizations and occupational health care. Aalto University publication series DOCTORAL DISSERTATIONS, 191/2013. (Abstract in English) https://aaltodoc.aalto.fi/handle/123456789/11464?show=full

[21] Alavi, M., Leidner, D.E. (2001). Knowledge Management and Knowledge Management Systems: Conceptual Foundations and Research Issues. MIS Quarterly, 25(1), (2001), 107-136. doi:10.2307/3250961

[22] Choo Chun Wei (2002). Information management for the intelligent organization: the art of scanning the environment. Review. Information Today. Medford: USA. 2002.

[23] Myllärniemi, J., Laihonen, H., Karppinen, H., Seppänen, K. (2012).

Knowledge management practices in healthcare services. Measuring

Business Excellence, 16(4), (2012), 54-65. https://doi.org/10.1108/13683041211276447

[24] Palmgren, H., Jalonen, P., Kaleva, S. (2008). Health education and communication in Occupational Health Services in Finland. Arh Hig Rada Toksikol, 59(3), (2008), 171-81. doi:10.2478/10004-1254-59-2008-1888

[25] Nissinen, S., Leino, T., Kinnunen, U.M., Saranto, K. (2016). Kokemuksia tietojen vaihdosta työterveysyhteistyössä: terveystarkastuksessa kirjattavat tiedot. FinJeHeW 8(2-3), (2016), 81-97. https://journal.fi/finjehew/article/view/58104

[26] Nissinen, S, Leino, T, Oksanen, T., Saranto, K. (2016). Relevant Patient Data for Health Information Exchange: A Delphi Method Study among Occupational Health Professionals. Occup Med Health Aff, 4, (2016), 244. doi:10.4172/2329-6879.1000244

[27] Salojärvi, S., Furu, P., Sveiby, K.E. (2004). Knowledge Management and Growth in Finnish SMEs. Journal of Knowledge Management, 9(2), (2004), 103-122.

https://citeseerx.ist.psu.edu/viewdoc/download?doi=10.1.1.90.3174\&rep=rep $1 \&$ type $=$ pdf

[28] Schmidt, L., Gunnarsson, K, Dellve, L., Antonsson, A.B. (2016).

Utilizing occupational health services in small-scale enterprises: a 10-year perspective. Small Enterprise Research, 23(2), (2016, 101-115.

doi:10.1080/13215906.2016.1221358 